\title{
DIE KERK IN EKUMENIESE PERSPEKTIEF
}

\author{
J. A. LOADER
}

Die Kerk is, soos ons later sal aandui, die een liggaam van Christus. Daarom is alle ekklesiologie Christologie. Ook dié hoofstuk van die ekklesiologie wat handel oor die kerk in ekumeniese perspektief is daarom ' $n$ Christologiese uitspraak oor die eenheid van die Kerk. En omdat die Skrif van Christus getuig, kan ons nooit oor die ekumene praat as ons dit nie uit die Skrif doen nie. Dit beteken dat ons nou 'n Skriftuurlike beeld van die kerk in ekumeniese perspektief moet gee voordat ons ons na die situasie waarin ons ons bevind, keer. Ons sal dus nou eksegese moet beoefen.

\section{A. PRINSIPIEÉL.}

(1) Eenheid - die Bybelse beskouing.

Dit is in die bestek van 'n referaat onmoontlik om 'n eksegetiese behandeling aan te bied van al die Bybelse passasies wat oor eenheid handel. Daarom beperk ons ons tot slegs twee van die momente wat in die huidige ekumeniese denke dikwels op die voorgrond tree, $\mathrm{nl}$. Joh. 17 en die begrip oikoumené.

(a) Johannes 17

Verse 11 en 20-23 van hierdie hoofstuk het die slagspreuk van die Ekumeniese Beweging geword. Ons sal eers ons eie uitleg aanbied en dit daarna vergelyk met die populêre „ekumeniese” gebruik.

Joh. 17 staan bekend as die Hoëpriesterlike Gebed van Christus. Ons kan die hoofstuk in drie hoofafdelings verdeel. In die eerste $(1-5)$ dra Christus sy eie werk aan die Vader op; die tweede $(6-19)$ is ' $n$ gebed vir Sy dissipels, en in die derde deel $(20-23)$ bid Christus vir die komende Christendom.

Dit gaan ons in hierdie referaat om die tweede en derde afdelings van die hoofstuk. Wie is nou, in die eerste plek, die dissipels? Die woord mathètès kom gladnie in die hoofstuk voor nie. Die dissipels word omskryf as almal wat die Vader aan die Seun gegee het $(2,6,9,11,12)$ of met die 
vorm van die derde persoon (voornaamwoord of werkwoordsvorm).

Hulle is dus diê wat aan Christus behoort en hulle is nie van die wêreld nie, maar ín die wêreld $(15,16)$. Vir hulle bid Christus nou dat die Vader hulle in sy waarheid sal afsonder (hagiazein) (17) - en Sy woord is die waarheid. Christus wil dus dat die aan Hom gegewe dissipels wat die woord van die Vader deur die Seun ontvang en bewaar het (6), afgesonder moet word om die woord van God te verkondig - en hierdie woord moet die ware woord wees (17)

Hierdie dissipels word nou apostels (18 apostello). Hulle moet die wêreld ingaan en die woord van God, die waarheid van God, verkondig. Dan sal daar ook ander mense wees wat deur die sendingsarbeid van hierdie eendragtige manne in Christus sal glo. Vir hulle bid $\mathrm{Hy}$ ook „dat almal een mag wees net soos $U$, Vader, in $M y$ en $E k$ in U" $(20-22)$. Die ná-aspostoliese gelowiges moet dus, net soos die apostelkring, één wees. En net soos die eenheid van die apostels, moet dit ' $n$ eenheid in die woord van God wees, d.w.s. ' $n$ eenheid in waarheid. Dan bind Christus aan hierdie eenheid 'n heerlike vooruitsig: „.. . . . sodat die wêreld kan glo dat u My gestuur het" (21). Die eenheid van die gelowiges het dus betekenis vir die sending. Ons kan nie saamstem met die uitleg van Van der Waal (pp. 48/9) dat "wêreld" (kosmos) in die Evangelie volgens Johannes sou aandui "de door de, 'God dezer eeuw' beheerste afvallige joodse kerk" nie. Joh. 3:16 word hierdeur onverstaanbaar. Die eenheid van die gelowiges het betekenis vir die sen. ding - dit is die enigste uitleg van vers 21 wat nie verniet kosmos gebruik nie. Ons stel dan dat die eenheid waarvan Joh. 17 praat, eenheid in die woord, in die waarheid is. Anders gestel: dit is 'n eenheid in Christus.

Nou gaan ons een stap verder: die hede van Christus tot die Vader word 'n imperatief aan die gelowiges. Die doelsin van vs. 21 (,,sodat die wêreld kan glo") word in die lig van die indikatief van vs. 18 ("Ek het hulle gestuur"): Gaan, verkondig die 
woord terwyl julle een is in die waarheid, sodat die wêreld kan glo.

Hierdie Bybelse opdrag tot eenheid is die motief vir die ekumene, en nie oorwegings soos 'n eenheidsfront teen modernisme, sekularisasie, ateisme en kommunisme nie. Hierdie lg. oorwegings kan alleen sekonder wees en nooit primêre motief nie. (Vgl. Engelbrecht p. 54).

Die eenheidsgedagte wat deur die Ekumeniese Beweging voorgestaan word, maak van Joh. 17 veel gebruik. Maar alleen op die klank af. Eenheid ten alle koste - ook ten koste van die waarheid. Dan word die eerste gedagte van Joh. 17 misken en die gedagte van eenheid word misvorm tot ' $n$ valse eenheid. (Vgl. Broeyer pp. 98-103 vir voorbeelde van wat ons noem valse eenheid). Ons wys dus die gedagte dat alle "Christene", wat hulle ookal aangaande Christus bely, een moet wees - een organisatoriese kerk moet word - af op grond van Joh. 17.

(b) Die begrip oikoumené

Die woord „ekumene” en sy bnw. „ekumenies” is dieselfde as die Griekse oikoumene. Dit is 'n heel paslike beskrywing vir die kerk as wêreldwye eenheid. Maar, soos ons uitgangspunt in die vorige paragraaf was, is dit ook hier noodsaaklik om die term „ekumene" in die N.T. se sin te gebruik omdat spreke oor die kerk spreke vanuit die Skrif moet wees. Ons sal daarom enkele relevante passasies in die N.T. moet nagaan om te sien in watter verband hierdie woord gebruik mag word.

Oikoumené is 'n praes. part. pass. f. van die werkwoord oikeo wat beteken om te woon of te bewoon. Die woord beteken dan „die bewoonde (wêreld)" (oikoumene(gé)). Dan ontwikkel dit tot die bewoners van die wêreld, dus "mensheid" (vgl. Hebreeus olam). In die NT. kom die woord vyftien keer voor.

Vir ons huidige doel kan ons van hierdie plekke, soos Luk. 2:1; 4:5 en Han. 19:27 buite rekening laat. Maar die oikoumene word ook gebruik in verbande wat lig werp op die „kerk in ekumeniese perspektief". 
In Matt. 24 praat Christus oor die teken van Sy wederkoms. Sy antwoord op die dissipels se vraag na 'n semeion is: "Pas op dat niemand julle mislei nie". (4-5). Hy waarsku teen valse Christi wat sal opstaan om hulle te mislei. En dan praat $\mathrm{Hy}$ van oorloë en aardbewings $(6-7)$. Hiermee sal verdrukking gepaard gaan (9). En dan sal ook verval t.o.v. die waarheid plaasvind, "maar wie volhard tot die einde toe, hy sal gered word". $(11-13)$. Die antwoord van Christus op sy dissipels se vraag na ' $n$ teken is dus ' $n$ antwoord op die waarheidsvraag. En pas dán, nadat $\mathrm{Hy}$ oor die ware evangelie van liefde gepraat het, som Christus die voorafgaande verse op: „En hierdie evangelie van die koninkryk sal verkondig word in die hele oikoumene tot ' $n$ getuienis vir al die nasies; en dan sal die einde kom" (14).

In hierdie perikoop word die sending in ekumeniese, d.w.s. ' $n$ wêreldwye lig gestel. Maar dan moet ons deeglik verstaan dat die evangelie wat vir die hele wêreld bestem is, die ware evangelie is. Oikoumene word hier nóú met die waarheidielement verbind. As in die ware evangelie volhard word, beteken dit die afwysing van die valse evangelie (vgl. 4-5, 10). Dat die kerk wat met die ekumeniese sendingsarbeid geplant moet word, een kerk is, is implisiet in die hele perikoop - trouens, in die hele NT. Maar hierdie kerk moet volhard in die ware evangelie van Christus.

Hierdie selfde verband met die waarheid kom ook in Hand. 17:31 voor. Paulus verkondig in die afsluiting van sy toespraak op die Areopagus dat die oikoumene betrek sal wees by die oordeel van God deur Christus. Daarom moet die evangelie aan die hele oikoumene verkondig word. Almal moet hoor want almal sal geoordeel word. Paulus se prediking is prediking van die waarheid. Ten spyte van die te verwagte aanstoot wat die leer van die opstanding van Christus by die Grieke sal gee, swyg hy nie daaroor nie. Hy verkondig 'n evangelie wat prikkel tot keuse - voor of teen. Sy prediking in die oikoumene het dus nie alleen die doel om te verenig nie, maar ook om uit te sluit. Dié wat nie glo nie, distansiëer hulle van dié wat eenheid in Christus gevind het.

Ook hier moet ons daarop wys dat die term oikoumene nie die betekenis het wat dit teenswoordig dra nie, maar dat dit die wêreldwye betrekking met die oordeel van God aandui. 
Ook in Rom. 10 word die wêreldwye verkondiging in verband gebring met die suiwere evangelie. Israel het die evangelie gehoor tot by die eindes van die oikoumene (18) (aanhaling uit Ps. 19:5 LXX - oikoumene vir die Hebreeuse qese tebel). Geen kompromie kan met diégene wat die evangelie hoor, waar hulle ookal in die oikoumene is, aangegaan word nie.

Ons kan nou uit die voorafgaande vasstel :

(i) Die evangelie is vir die hele mensheid.

(ii) Die evangelie wat aan alle mense verkondig word, moet die suiwere evangelie wees.

(iii) In hierdie evangelie moet almal één wees. En omdat dit 'n evangelie van Jesus Christus is, kan ons sê dat almal in Hom een moet wees.

(iv) Hierdie eenheid sal dan verder missionêre krag hê.

(v) Niemand wat die evangelie verwerp het, is ingesluit in die ekumeniese, wêreldwye eenheid nie.

\section{Kort ekskurs oor die moderne gebruik van die term oikoumene}

Die Ekumeniese Beweging pretendeer om die eenheid van Christus dwarsoor die wêreld te bevorder. Vir so 'n beweging is die naam "Ekumeniese Beweging" uiters geskik. Ons wil hier daarop wys dat die b.nw. „ekumenies" in die spraakgebruik van vandag al meer gaan beteken het "wêreldwye eenheid" terwyl dit nie die betekenis van die oorspronklike Grieks is nie. Maar op sigself is daar niks mee verkeerd om die eenheidsgedagte aan die woord te verbind nie. Voorwaarde daarvoor is egter dat, aangesien die Bybelse konsepsie van eenheid daaraan gegee wil word, ook en veral die Bybelse inhoud aan „eenheid" gegee moet word.

Ons het tot dusver eers die eenheid van die gelowiges behandel, en daarna enkele passasies waarin die oikoumene vermeld word. Dit het ons met opset gedoen om aan te dui dat die eenheid in Christus primêr kwalitatief verstaan moet word, en daarnaas eers kwantitatief. Maar in die hedendaagse Ekumeniese denke word die volgorde omgekeer (vgl. Broeyer pp. $101-103$ vir illustrasies). So kon die Evanston-vergadering van 1954, waar persone van alle konfessies byeengekom het, ver- 
klaar: "Ons is van plan om ons te verenig". Dit was 'n taamlik radikale verandering van die Amsterdamse vergadering (1948) se uitspraak: "Ons is van plan om byeen te bly". Die belangrikste is dat "Christene" oor die hele wêreld een is, en dit sigbaar is. Maar wie hulleself Christene noem en watter voorveronderstellings daar vir hierdie eenheid is, kom in die tweede plek - indien dit 'n plek kry. Wel word gesê dat die eenheid 'n gemeenskap is ..... van kerke, wat die Heer Jesus Christus as God en Heiland ooreenkomstig die Heilige Skrif bely en wat daarom hul gemeenskaplike roeping gesamentlik wil vervul tot eer van die een God, Vader, Seun en Heilige Gees". (Basisformule van die vergadering van die Wêreldraad van Kerke, Nieu Delhi, 1961). Maar verder kan daar nie gekwalifiseer word nie, want die „eenheid in Christus" sal dan vernietig word. So sien selfs genootskappe wat die Triniteit verwerp, kans om hierdie basisformule te onderskryf. Die laaste $\sin$ is dan só geformuleer dat dit ' $n$ liturgiese lofprysing vorm en daar is 'n komma na die woord "God"; daarom kan daar hier 'n verwysing na die Triniteit verstaan word, of die Triniteit kan geloën word met die onderskrywing van die formule!

"Ekumene" beteken dan vir die Wêreldraad ' $n$ eenheid van die grootste gemene deler. Dus buite die waarheid om. So 'n eenheid is nie die Bybelse begrip van eenheid (oor die hele wêreld) in Christus nie. Die Bybel wil ' $n$ ekumeniese sendingsarbeid en die noodwendige eenheid as gevolg daarvan. Die Wêreldraad ook. Maar die valse evangelie het geen aanspraak op gemeenskap met die ware nie (Vgl. II Kor. 6:14).

(2) Is die eenheid sigbaar of onsigbaar?

As die kerk slegs onsigbaar is, is die eenheid ook onsigbaar. Dan is die idealisme van Plato nuttig om die eenheid te illustreer. Vir sover alle kerke op een of ander wyse deel het aan die onsigbare idee waarheid-in-Christus, is almal ware kerk en een in Christus.

Maar die kerk is nie bloot onsigbaar nie. Ons het aan die begin gesê ekklesiologie is Christologie. Die kerk is die liggaam van Christus (Rom. 12:4-5; I Kor. 10:16 17, 12:12 - 13; Ef. 1:22 - 23, 4:12, 5:23, 29 -30; Kol. 1: 18, 24). Jesus van Nasaret was sigbaar. Maar dat $\mathrm{Hy}$ Seun van God is, is nie sigbaar nie - dit is geloofsaak. 
Die kerk is liggaam van Christus, en 'n liggaam is sigbaar. "Maar dat dit zichtbare lichaam Kérk is, het lichaam van Christus, dát kan ik niet zien -, dat is zaak van geloof." (Van Niftrik. p. 269). Die kerk is dus sigbaar in dié sin dat hy sigbaar gestalte aanneem in die wêreld, onsigbaar in dié sin dat hy ware kerk van Christus is. Op die Roomse argument dat, as die kerk geestelik in volstrekte sin is, niemand hulle daarby sal kan voeg nie, antwoord Luther: .Ofskoon die kerk vlees het, leef hy nie na die vlees nie." So is ook die eenheid van die kerk sigbaar en onsigbaar tegelyk. Anders gestel: die kerk móét een wees en die kerk is. Dit bring ons nou by die punt waar ons moet vasstel hoe die kerk sy eenheid aan die lig moet bring - dié eenheid wat reeds daar is.

(3) In hierdie verband moet ons eers daarop wys dat die eenheid van die kerk ook eenheid met die kerk beteken. (Vgl. die Nederlandse Geloofsbelydenis: Art XXVIII volg nie verniet op Art. XXVII nie; vgl. ook Calvyn, Inst. IV. 1 , ii). Dit beteken dat daar tekens moet wees vir die mense dat hulle kan weet waar om hulle by die ware kerk te voeg. Hierdie notae is die regte prediking en geloof, die regte Sakramentsbediening en die regte lewe in liefde (wat dan die tug insluit). (Vgl. NGB Art. XXIX en Calvyn Inst. IV, I, vii-iX). By so 'n kerk moet die Christen hom dan voeg. En tussen sulke kerke bestaan daar 'n Godgegewe eenheid, 'n eenheid wat hierdie kerke dan gestalte moet gee - tensy hulle verkies om platonies te dink.

Beteken dit dan dat alleen kerke wat honderd persent, in alles, met mekaar eens is, één kan wees? Hoe wyd moet ons die Bybelse eenheid in prediking, sakrament en lewe verstaan? M.A.W., wat is die capita doctrinae qua ecclesia Christi fundatur? In hierdie verband is dit insiggewend om Calvyn se formulering te gebruik omdat dit helder en eenvoudig is.

Om Calvyn se siening weer te gee, moet ons eers die historiese verband waarin hy hieroor gepraat het, aandui. Eerstens kan ons op die kontroversie tussen die Calvinisme en die Lutheranisme oor die Nagmaal wys, en ook op Calvyn se ontslag van Castellio oor die verskil t.o.v. die hellevaart. Calvyn het Castellio ontslaan (in 1545) m.b.t. die doctrina (die leer), maar hom nie verdoem tot iemand wat die ware evangelie 
verlaat het nie. Presies dieselfde gebeur in 1551 toe Calvyn Bolsec uit die Calvinistiese Kerk sluit omdat Ig. die Lutherse predestinasieleer aanvaar. Maar tegelykertyd beveel hy die Loci Communes van die Lutheraan Melanchton sterk aan omdat daar so baie in gevind word wat gemeenskaplik met die Calvinisme is. ( $\mathrm{ggl}$. Engelbrecht p. 64).

Hierdie capita doctrinae is volgens Calvyn die leer „,aangaande die enige en ware God en Sy wettige diens, aangaande die verdorwenheid van die menselike geslag, aangaande die onverdiende, vrye saligheid, aangaande die wyse waarop die geregtigheid verkry word, aangaande die boetedoening, aangaande die geloof, wat berus op die beloftes van die Evangelie, en die sekerheid van die Saligheid aan ons skenk, omtrent die aanroeping van God." (Engelbrecht p. 64).

Volgens Calvyn is die belydenis dus rekbaar. Nie enigiets kan geglo word nie, maar binne die raamwerk van die capita doctrinae is daar ruimte vir ecclesiae contraversa wat nie die fidei unitas te niet doen nie. Wesenlik is daar dus een kerk wat in die geloof in Christus sy eenheid het en hierdie geloof in Christus word geformuleer in die capita doctrinae. Maar vir sover daar verskillende confessiones (belydenisse) binne hierdie eenheid is, is hulle in verskillende genootskappe georganiseer. Een kerk mag nie ' $n$ ander, binne die capita, verdoem nie (non improbare). Die kerk moet dus volgens Calvyn één wees, maar nie noodwendig eens nie. Hierdie sienswyse, en dit is van uitsluitende belang. Dieselfde Paulus wat sê: "As iemand 'n evangelie verkondig in stryd met dié wat julle ontvang het, vervloek sy hy! (Gal. 1:9), sê ook: „Die een ag die een dag bo die ander, die ander ag al die dae gelyk. Laat elkeen in sy eie gemoed ten volle oortuig wees!" (Rom. 14:15).

\section{B. KONKLUSIE.}

Ons moet nou ons prinsipiële standpunt in die praktyk toepas. Hier kom twee gesigspunte na vore, $n l$. ' $n$ negatiewe en 'n positiewe.

(1) Die volstrekte negasie.

Wanneer ons in ontmoeting kom met 'n genootskap wat op die naam "Christelike kerk" aanspraak maak, moet die belydenis (indien enige!) van so 'n genootskap aan die 
Skrif gemeet word. Voldoen hierdie belydenis nie aan die eis van Skriftuurlikheid nie, moet ons ' $n$ ernstige anathema sit oor so 'n leer uitspreek.

In ' $n$ verklaring van die Kommissie van Geloof en Kerkorde van die Wêreldraad van Kerke (1960) lees ons die volgende: „Die eenheid, die zowel Gods wil as Zijn gave aan de kerk is, brengt in iedere plaats allen die Christus beleden in hechte gemeenschap te samen..." (aangehaal deur Van der Waal p. 29). Dit alles klink wel mooi, maar wat onder "die Christusbeleden" verstaan word, blyk uit die volgende: In die wêreldkerk is daar plek vir Unitariërs wat die Triniteit ontken, Oostersortodokses wat die filioque verwerp, en Rome wat in die mis ' $n$,vervloekte afgodery" bedryf (Calvyn). Van ooreenstemming in die capita doctrinae is hier geen sprake nie.

Dít is die rede waarom die Ned. Herv. Kerk nie lid kan wees van die Wêreldraad nie. Daarby kom nog ander sake, wat gevolg is van die geringskatting van die leer, maar wat nie die primêre radix van die afwysing van die ekumeniese beskouing van die Wêreldraad is nie. Voorbeelde hiervan is o.a. die Evanstonkonferensie van 1954 se klem op die politieke en sosiale taak van die kerk (vgl. Broeyer pp. 98/9, en die aanvalle van die Cottesloebesluit op die Regering van Suid-Afrika (vgl. bv. Besluite, Afd. B:11, 13 en 15 en vgl. daarmee Afd. B:6). Geringskatting van die belydenis is dieselfde as verwerping van die belydenis. Daarom kan ' $n$ kerk wat kerk van Christus wil wees, nie toelaat dat hy betrek word in ' $n$ eenheidspoging bloot ter wille van die eenheid nie - al word daar nóg soveel „voordele” van een wêreldkerk opgenoem.

Waar daar so oor die capita doctrinae heengestap word, het die kerk nogtans 'n ekumeniese taak: die verkondiging van die ware eenheid in Christus.

Maar ook met Rome kan ons nie een wees nie. Rome noem homself "die” Katolieke Kerk. In die ensikliek Mortalium Animos, 1928, stel Pous Pius XI dat die enigste weg tot eenheid terugkeer na die kerk van Rome is (Broeyer pp. 93/4). Hier beteken dit weer ' $n$ opoffering van die Skriftuurlike belydenis, en ons moet antwoord anathema sit. Nogtans het ons teenoor Rome in ekumeniese taak. Dit is om ons standpunt by her- 
haling te stel. Omdat ons teenswoordig as „afgeskeie broeders" by Rome bekend staan, en omdat Rome bereid is om met ons in gesprek te tree moet ons van die geleentheid gebruik maak om ons ekumeniese taak uit te voer - en dit biddend te doen.

(2) Die eenheid binne die capita doctrinae.

(a) .Ten opsigte van dié reformatoriese kerkgenootskappe waar daar tussen ons en hulle nog controversa bestaan, daar moet ons onderling in die ekumeniese gesprek ons daarvoor beywer om nie alleen die bestaande capita doctrinae te ontdek en te herontdek nie, maar om ook die fondamentele basis al wyer uit te bou." (Engelbrecht p.66).

(b) T.o.v. dié kerke wat dieselfde belydenis het as ons, sien die ekumeniese taak daar anders uit. Prinsipieël is daar nie 'n ekumeniese gesprek oor die capita doctrinae nodig nie, omdat daar ten opsigte hiervan nie contraversa bestaan nie. Maar daar is tog wat ons kan noem „kleiner controversa" wat die leer nie aantas nie. Ons dink byvoorbeeld aan verskille t.o.v. die aanvaarding of verwerping van die letterlike inspirasie van die Skrif, meer gevoelsmatige prediking, die sing van gesange in die erediens, sendingbeleid en liturgiese verskille by die viering van die Nagmaal.

Hier sal dit sigbare uitdrukking van ons eenheid in Christus wees as ons die verskille duidelik formuleer en bespreek. So sal dit duidelik word in hoe 'n mate die drie Afrikaanse kerke met mekaar kán saamwerk. En so sal dit ook duidelik word hoe hierdie drie kerke met andere kan saamwerk. Ons dink in hierdie verband aan die Gereformeerde Ekumeniese Sinode. Dan sal dit vir ons duidelik word dat daar nie alleen in Korinthe verskeidenheid van gawes bestaan het nie.

Ons meen dat ons dit in die verloop van ons betoog duidelik gestel het dat ons organisatoriese vereniging nie as noodsaaklik ag vir die manifestasie van ons reeds bestaande eenheid nie. Ons is een. En as verskeie lede van dié eenheid kan ons die ekumeniese taak onder mekaar deur samewerking aanvaar. En hierin het ons die heerlike wete dat Christus ook aan óns gedink het met sy woorde: ,En ek het hulle die heerlikheid gegee wat U My gegee het, sodat hulle een kan wees, net soos Ons een is" (Joh. 17:22). 


\section{AANGEHAALDE GERAADPLEEGDE WERKE}

Barth, Karl,

Broeyer, F. G. M.,

Calvyn, Joh.

Engelbrecht, B. J. e.a.,

Henderson, J.,

Polman, A. D. R.,

Smelik, E. L.,

Treurnicht, A. P.,

Van der Waal, C.,

Van Niftrik, G. C.

Van Selms, A.,

Van Staden, A. J.,
"Dogmatik im Grundriss"

“De jongste tijd in Geschiedenis van de Kerk".

"Institusie".

"Die Kerk en die Ekumene".

"Power without Glory".

"Woord en Belijdenis".

"De Weg van het Woord".

"Onze Nederlandsche Geloofsbelijdenis".

"Op die Keper".

"Liquidatie der Reformatie".

"Kleine Dogmatiek".

"Lig uit Lig".

"Nuwe ekumeniese kontakte met kerke in die Buiteland"

(Memorandum, ongepubliseer). 